\title{
The Impact of Competence and Work Environment on Employee Motivation and Performance in The Financial and Asset Management Division
}

\author{
Nursaid $^{1}$, Keke Sulalatin FATHIAH ${ }^{2}$, Ni Nyoman Putu MARTINI ${ }^{3}$, Abadi SANOSRA ${ }^{4}$, Nurul \\ QOMARIAH ${ }^{*}$
}

\author{
1,2,3,4,5 Master of Management Postgraduate Program Universitas Muhammadiyah Jember, \\ E-mail: nursaid@unmuhjember.ac.id ${ }^{1}$, sulalatinkeke02@gmail.com², ninyomanputu@unmuhjember.ac.id ${ }^{3}$ \\ abadisanosra@unmuhjember.ac.id ${ }^{4}$, nurulqomariah@unmuhjember.ac.id ${ }^{5}$
}

${ }^{*}$ Corresponding Author

\author{
Received: 16.08.2021 \\ Accepted: 01.10.2021 \\ Published: 02.12.2021 \\ DOI: $10.47750 / Q A S / 22.185 .08$
}

\begin{abstract}
The Regional Financial and Asset Management Agency is a regional financial management technical institution that is responsible for creating a regional financial management system that is synergized and integrated with all Regional Apparatus Organizations (OPD) aimed at improving the quality of asset data that supports regional balance sheets. The not yet optimal performance of the Regional Financial and Asset Management Agency at the Bondowoso Regency Government, which is famous for producing coffee with the aim of exporting, needs to be done with the aim of improving employee performance. The novelty of this research is the improvement of performance at the Regional Financial and Asset Management Agency by considering employee competence, work environment and employee motivation. This study aims to determine the impact of employee competence, work environment on work motivation and employee performance at the Regional Financial and Asset Management Agency of Bondowoso Regency. The number of employees at the Regional Financial and Asset Management Agency of Bondowoso Regency is 61 employees, all of which will be sampled in this study. Thus the sampling technique in this study is the saturated sample technique. The analysis technique used is the Structural Equation Model (SEM) using WarpPLS 5.0. The results of data analysis show that the variables of employee competence, work environment and work motivation have a significant effect on employee performance. Variables of employee competence and work environment have a significant effect on employee work motivation. Work motivation has a significant effect on employee performance.
\end{abstract}

Keywords: employee competence, work environment, work motivation, employee performance

\section{Introduction}

In Law 5 of 2014 concerning the State Civil Apparatus, it is explained that civil servants and government employees are professions bound by work agreements working for government agencies. ASN is regulated by a separate law, namely Law 5 of 2014 concerning the state civil apparatus. Law Number 5 of 2014 concerning State Civil Apparatus was ratified by the fifth President of the Republic of Indonesia, namely Susilo Bambang Yudhoyono on January 15, 2014. To realize national goals and implement the nation's ideals, civil servants are needed. Employees of the state civil apparatus are entrusted with the task of carrying out public service tasks, government duties, and certain development tasks, it is necessary to build a state civil apparatus that has integrity, is professional, neutral and free from political intervention, is free from practices of corruption, collusion and nepotism, and able to provide public services for the community and able to carry out the role as an element of national unity and integrity based on Pancasila and the 1945 Constitution of the Republic of Indonesia. the qualifications possessed by candidates in recruitment, appointment, placement, and promotion to positions in line with good governance and to realize the state civil apparatus as part of bureaucratic reform, it is necessary to establish the state civil apparatus as a profession that have the obligation to manage and develop themselves and are obliged to account for their performance and apply the principle of merit in the implementation of the management of the state civil apparatus (https://www.jogloabang.com/pustaka/uu-5-2014-aparatursipil-negara-asn). To realize national goals, it is necessary to have civil servants assigned to carry out public service tasks, government duties, and certain development tasks. Public service duties are carried out by providing services for goods, services, and/or administrative services provided by state civil servants. The government's tasks are carried out in the context of implementing general government functions which include the utilization of institutions, staffing, and management. Meanwhile, in the context of the implementation of certain development tasks, it is carried out through nation building as well as through economic and social development directed at increasing the welfare and prosperity of the entire community. In carrying out their duties, the state civil apparatus is required to provide the best service to the community. Services to the community must be provided so as to provide satisfaction to the community. If the services provided can provide a level of satisfaction to the community, it can be said that the state civil apparatus has performed well. 


\section{Literature Review and Hypotheses}

Performance is the result of work in quality and quantity achieved by an employee in carrying out his functions in accordance with the responsibilities given to him (Azhad et al., 2015). According to (Mangkunegara, 2010) performance is the result or output of a process carried out by an employee. (Luthans, 1995) suggests that performance is the quantity or quality of something produced or services provided by someone who does the job. (Mulyadi, 2016) suggests that performance is work performance, namely the comparison between work results and established standards. Employee performance is the result of work achieved by a person in carrying out assigned tasks including the quality and quantity of output as well as reliability at work. Many factors can improve the performance of an employee or employee. Several factors are indicated to improve employee performance, among others: competence, work environment and work motivation.

Competence is the knowledge, skills, and abilities possessed by a person, which are part of him, so that he can carry out certain cognitive, affective, and psychomotor behaviors to complete his tasks (Hutapea, 2008). A person's competence indicates the achievement and maintenance of a level of understanding and knowledge that allows a member to provide services with ease and ingenuity (Mulyadi, 2016). Competence is a basic characteristic of a person that allows employees to issue superior performance in their work so that they can provide the best results (Mangkunegara, 2010). The relationship between employee performance can be illustrated that employees who have in accordance with the field of work being occupied will give the best results. Research on the relationship between competence and employee performance has been put into research. (Amdani et al., 2019) conducted a study on Medan Polytechnic Ganesha and the result is that competence has a positive and significant effect on the performance of Medan Ganesha Polytechnic employees. Research from (Yamin \& Ishak, 2018), (Wasiman, 2020), (Sriwidodo \& Haryanto, 2010), (Basalamah, 2017), (Friolina et al., 2017), (Mukhtar, 2018), (Setiawati, 2017), (Nyoto et al., 2020), (Pinca, 2015), (Sujana, 2012), (Ataunur \& Ariyanto, 2015), (Indiyaningsih et al., 2020), (Amdani et al., 2019), (S. Manik \& Syafrina, 2018), (Rande, 2016), (Mustikawati \& Qomariah, 2020), (Sulistyo et al., 2016), (Kapahang et al., 2014), (Mananeke et al., 2014), (Herawati \& Mahfudnurnajamuddin, 2018), (Abdi \& Wahid, 2017), (Pujiarti, 2019), (Winanti, 2011), (Friolina et al., 2017), (Renyut et al., 2017), (Marhayani et al., 2019), (Abusama et al., 2017), (E. Manik \& Wiarah, 2014), (Basriani, 2016), (Prijono et al., 2019), (Mananeke et al., 2014), (Sholehatusya'diah, 2017), (Saban et al., 2020) states that employee competence can improve employee performance. Several studies which state that competence has no effect on employee performance include: (Bahri et al., 2018), (Adam \& Kamase, 2019), (Utomo et al., 2019) (Wongso et al., 2020), (Chandra et al., 2020).

According to (Nitisemito, 2008), the work environment is everything that is around work and can affect an employee in carrying out the tasks assigned to him. The work environment is the whole of tools and materials faced by the surrounding environment in which a person works, his work methods, and work arrangements both as individuals and as groups (Sedarmayanti, 2011). The work environment is the overall work facilities and infrastructure around employees who are doing work that can affect the implementation of the work itself (M. S. P. Hasibuan, 2016). (Sarwono, 2005) states that the work environment is a collection of work environments in a place that has an impact on employee morale, as well as productivity both positively and negatively. The relationship between the work environment and employee performance is very close. Physical work environment in the form of office space, lighting, coloring can make the work atmosphere comfortable. The non-physical work environment in the form of good relations between employees and co-workers and leaders can also have an impact on employee performance. A comfortable physical and non-physical environment will increase a person's performance in completing tasks from superiors. Research from (Kurniawat \& Tobing, 2019), (Rozalena et al., 2018), (Anggitaningsih \& Handriyono, 2019), (Soetikno, 2017), (Indris \& Primiana, 2015), (Adha et al., 2019), (Aktarina, 2015), (Dessy et al., 2018), (Marhayani et al., 2019), (Iskandar \& Juhana, 2014), (E. A. Hasibuan \& Afrizal, 2019), (Pioh \& Tawas, 2016), (Novitasari et al., 2012), (Sugiyatmi et al., 2016), (Hafifi et al., 2018), (Priyono et al., 2018b), (Yohana et al., 2020), (Kurniawati \& Tobing, 2019), (Kapahang et al., 2014), (Bentar et al., 2017), (Fachreza et al., 2014), (Husnah et al., 2018), (Feel et al., 2018), (Firdaus et al., 2017), (Siregar et al., 2020), (Ardianti et al., 2018), (Susanti, 2017), (Suwondo \& Sutanto, 2015), (Komaling et al., 2016), (Priyono et al., 2018b), (Abdi \& Wahid, 2017), (Parhusip et al., 2020) states that a comfortable work environment can improve employee performance. Meanwhile research (Riansari et al., 2012) states that the work environment has no impact on employee performance.

The driving force that exists within a person is often called a motive. The driving force outside of a person must be generated by the leadership and so that things outside of a person's self also influence him, the leader must choose various means or tools that are suitable for other people. Motivation questions how to direct the power and potential of subordinates so that they want to work together productively to achieve and realize the goals that have been determined (Simamora, 2006). Motivation is something that moves or encourages a person or group of people to do or not do something (Mu'ah, 2002). Motivation can also be interpreted as a factor that gives hope, namely hard work in achieving expected achievements with achievements that can provide results for the benefit of the activities carried out (Mangkunegara, 2010). Motivation can be defined as something that pushes someone to do something and expends all his effort and energy for it. The nature and intensity of each person's motivation varies depending on the various influences that exist at a certain time (Mulyadi, 2016). If motivation is associated with employee performance, it will provide a very important role. With someone's motivation to get achievements and awards, the performance of an employee will also increase. Research on the role of motivation that can improve employee performance has been done a lot. Several studies which state that work motivation can improve employee performance include: (Sriwidodo \& Haryanto, 2010), (Sujana, 2012), (Ahmad et al., 2014), (Vidianingtyas \& Putri, 2014) (Hermawan, 2015), (Komaling et al., 2016), (Achmad, 2016), (Brury, 2016), (Wibowo \& Putra, 2016), (Lopes, 2016), (Solikah et al., 2016), (Abusama et al., 2017), (Sumowo, 2017), (Ariono, 2017), (Riantoko et al., 2017) (Gala et al., 2017), (Firdaus et al., 2017), (Basalamah, 2017), (Perdana, 2018), (Sya'roni et al., 2018), (Priyono et al., 2018a), (Manggis et al., 2018), (Kosasih, 2018), (Hidayah \& Tobing, 2018), (Koni, 2018), (Adam \& Kamase, 2019), (Adha et al., 2019), (Samah et al., 2019), (Kurniawan et al., 2019), (Permana et al., 2019), (Soebyakto et al., 2019), (Hendrawijaya et al., 2019), (Kurniawati \& Tobing, 2019), (Utomo et al., 2019), (Paais \& Pattiruhu, 2020), (Atikah \& Qomariah, 2020), (Qomariah, Hermawan, et al., 2020) (Hardianto et al., 2020), (Mayangsari et al., 2020), (Sari et al., 2020), (Wijianto et al., 2020), (Istanti et al., 2020), (Qomariah, Hermawan, et al., 2020), (Pancasila et al., 2020), (Qomariah, Warsi, et al., 2020).

While research which states that work motivation does not have an impact on employee performance include: (Brahmasari \& Suprayetno, 2008), (Dolphina, 2012), (Muhammad Arifin, 


\section{GENERAL MANAGEMENT}

2015), (Changgriawan, 2017), (Julianry et al., 2017), (Hanafi \& Abadi, 2018).

In addition to employee performance, a factor that needs to be considered by every organization or institution, whether it is state-owned or private, is the work motivation of its employees. Motivation questions how to direct the power and potential of subordinates so that they want to work together productively to achieve and realize the goals that have been determined (Simamora, 2006). Motivation is the driving force for employees to work even harder. Motivation can be in the form of encouragement to get appreciation from superiors, encouragement to improve performance so that it gets appreciation from the community. Several factors that can increase work motivation include competence and the work environment in which employees work. Research (Ngattemin \& Arumwati, 2012) demonstrate that competence has positive and significant impact on employee motivation hotel with a significant level of $2 \%$ at $\alpha=5 \%$. Another research that also discusses the problem of the relationship between competence and motivation is that conducted by (Zubaidah, 2016) the result is that to increase the motivation of SMPN Palembang teachers, it is necessary to further improve teacher competence. (Prahiawan et al., 2017), (Rahim et al., 2017), (Meidita, 2019) conducting research which results in the competence possessed by employees can motivate employees to work even harder.

Work motivation can increase due to a comfortable work environment. A physical work environment is necessary for employees to work even harder. The physical environment that can provide comfort in working can be in the form of environmental cleanliness, lighting, air circulation and spatial planning. (Prahiawan et al., 2017) conduct research that connects the work environment with employee work motivation whose research results are the work environment at PT. Krakatau Bandar Samudera can increase work motivation. (Prakoso et al., 2014) states that work environment affect the job performance of employees through motivation, which means that a pleasant working environment can motivate employees to work better so as to improve employee performance. (Marwanto \& Nugroho, 2014) stated that the work environment variable had a significant positive effect on the work motivation of soldiers in the KRI X Fleet Eastern Region Work Unit.

Based on the theory of improving employee performance and motivation based on competence and the work environment that exists in the institution or organization and also based on research that has been carried out by several researchers, the research hypotheses that can be developed in this study include 5 research hypotheses. The hypotheses in this study are:

H1: Employee competence can increase employee work motivation.

H2: A comfortable work environment can increase employee motivation.

H3: Employee competence can improve employee performance.

H4: A comfortable work environment can improve employee performance.

H5: Work motivation can improve employee performance.

Based on the research hypothesis that has been developed, the conceptual framework in this study can be seen in Figure 1 below.

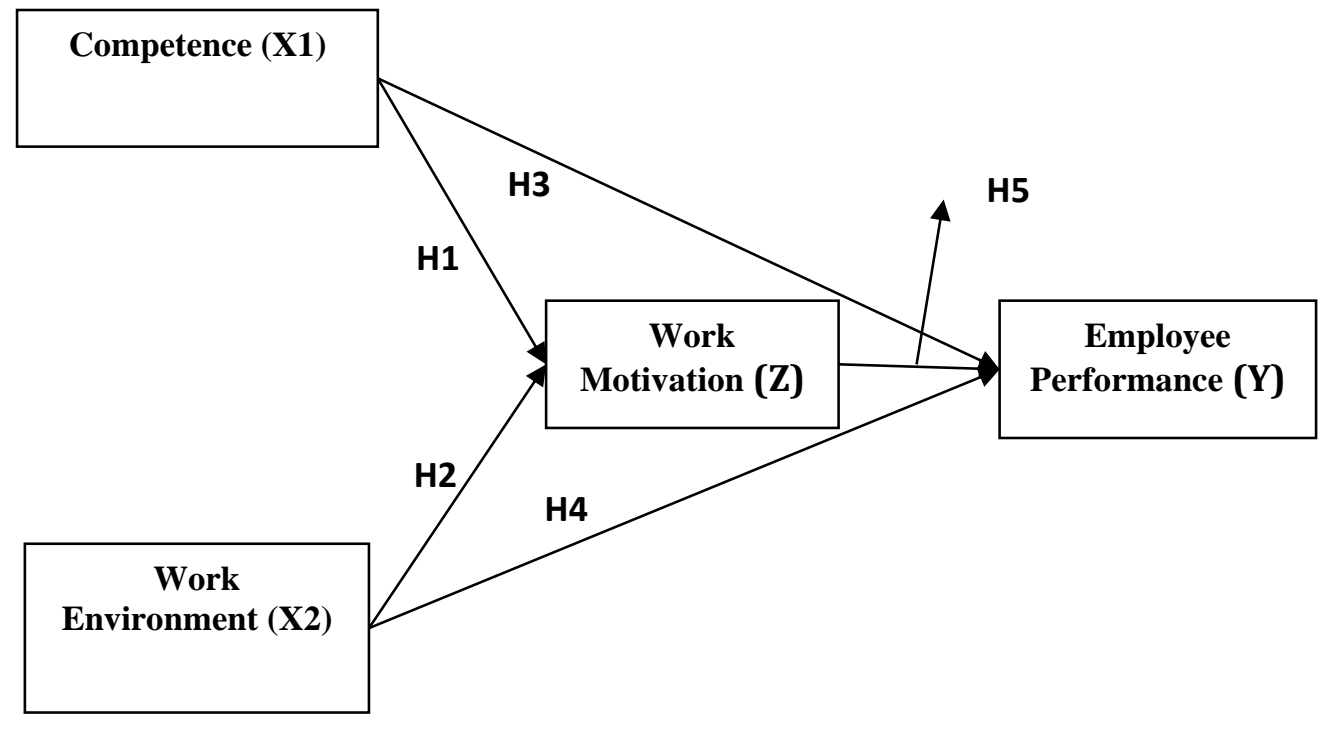

Figure 1: Conceptual Framework

This research was conducted at the Regional Financial and Asset Management Agency of Bondowoso Regency. As for the strategic issues that need serious attention and handling in the implementation of the main tasks and functions of the Regional Financial and Asset Management Agency for the next 3 (three) years, among others: 1) the utilization of regional assets is still not optimal as a source of retribution revenue; 2 ) there is still a need for competent personnel in the field of asset valuation for the preparation of balance sheets in order to accelerate the overall financial statements; 3 ) competent human resources in the field of information technology and infrastructure are still needed for SIMDA applications. With regard to the theory that has been described and also based on previous research that has been carried out by previous researchers and based on the problems that are still faced by the Regional Financial and Asset Management Agency of Bondowoso Regency, there are 3 (three) research questions that need to be answered, namely: 1) first, Can the competencies possessed by employees increase employee work motivation? Second, can a good work environment increase employee motivation? Third, can the competencies possessed by employees improve employee performance? Fourth, can the work environment improve employee performance? Finally, can work motivation improve employee performance at the Regional Financial and Asset Management Agency of Bondowoso Regency?. The research conducted at the Regional Financial and Asset Management 
Agency of Bondowoso Regency is expected to have five objectives. The first objective is to determine the effect of employee competence on employee work motivation. Second, to determine the effect of the work environment on employee motivation. Third, to determine the effect of employee competence on employee performance. Fourth, to determine the effect of the work environment on employee performance. Finally, to determine the effect of work motivation on employee performance. . This study also contributes to the human resource management literature that focuses on improving the relationship between employee competence and the work environment on employee motivation and performance. This research also contributes to the Regional Work Units in each Level II Regional Government in each province related to increasing employee motivation and performance.

\section{Research Methods}

In this study, descriptive and quantitative research methods are used, which are methods for analyzing data by describing or describing the data that has been collected as it is without the intention of making conclusions (Sugiyono, 2017). The variables in this study have 3 (three) kinds of variables. First, the independent variable which consists of competence and work environment. Second, the intervening variable is work motivation. Third, the dependent variable is the employee performance variable. Each variable has dimensions that will later be used as a measuring tool in conducting research.

Each variable has dimensions that will later be used as a measuring tool in conducting research. (Nyoto et al., 2020) stated that the dimensions of the competency variable include:

1. Knowledge, namely awareness in the cognitive field. For example, an employee knows how to identify learning, and how to do good learning according to the needs that exist in the company.

2. Understanding, namely the cognitive and affective depth possessed by the individual. For example, an employee in carrying out learning must have a good understanding of the characteristics and working conditions effectively and efficiently.

3. Value, is a standard of behavior that has been believed and psychologically has been integrated in a person. For example, the standard of behavior of employees in carrying out their duties (honesty, openness, democracy, etc.).

4. Ability, is something that is owned by an individual to carry out the tasks or work assigned to employees. For example, the standard of behavior of employees in choosing work methods that are considered more effective and efficient.

5. Attitudes, namely feelings (happy-not happy, likesdislikes) or reactions to a stimulus that comes from outside. For example the reaction to the economic crisis, the feeling of a salary increase.

The second independent variable is the work environment with its dimensions, among others (Marwanto \& Nugroho, 2014) stating that:

1. Cleanliness of the work environment, indirectly the work environment can affect someone at work. Employees will feel more comfortable in doing their jobs if the work environment can be kept clean.

2. Lighting, which is meant not only lighting sourced from lights or electricity at night. But also lighting from the sun during the day.

3. Air exchange, namely the physical fitness of employees will increase when the room provides sufficient air exchange. The health of employees will be guaranteed if the room is adequate with ventilation.

4. Security guarantees, namely the existence of security guarantees for employees enough to provide employees with peace of mind at work.

5. Spatial planning, namely a good room arrangement will further encourage the creation of employee comfort at work.

(Permana et al., 2019) stated that the dimensions of the work motivation variable using Maslow's Theory are:

1. Physiological needs, namely the need to eat, drink, housing and sexual. This need is the most basic for humans. In working, the needs of employees that must be met is a decent salary/wages.

2. The need for a sense of security, namely the need for protection from the threat of danger and the work environment. In working, employees need health benefits, insurance and pension funds.

3. Social needs, namely the need to be accepted in a group and to love each other. In this relationship, employees want to be accepted at work, have good and harmonious work interactions

4. Self-esteem needs, namely the need to be respected and appreciated by others. In this relationship, employees need appreciation and recognition and not be treated arbitrarily.

5. Self-actualization needs, namely the need to develop oneself and potential. In this relationship, employees need opportunities to grow and develop personally.

The dimensions of employee performance use the theory proposed by (Gomes, 2010), namely:

Quality of work, namely the quality achieved based on the terms of suitability and readiness.

Quantity of work, namely the amount of work done in a specified time period.

Job knowledge, namely the breadth of knowledge about work and skills.

Creativeness, namely the originality of ideas that arise from actions to solve problems that arise.

Cooperation, namely the willingness to cooperate with other people (fellow members of the organization).

(Sekaran, 2006) provides a general reference for determining sample size, namely that in mutivariate research (including multiple regression analysis), the sample size should be 10x larger than the number of variables in the study. The number of variables in this study are 4 variables, when multiplied by 10 it is obtained 40 . Thus, the minimum sample size in this study is at least greater than 40 respondents. The Regional Financial and Asset Management Agency of Bondowoso Regency has a total of 61 employees ranging from management to lower-level employees. Thus the number of population in accordance with the criteria of this quantitative research is greater than 40 respondents, namely 61 employees. The sampling technique in this study is the saturated sampling technique. Saturated sampling is a sampling technique where the entire population is used as a research sample (Ghozali, 2013). Due to the total population of 61 employees, the sample in this study is also 61 employees. The unit of analysis in this study is the employees of the Regional Financial and Asset Management Agency of Bondowoso Regency, the number of which is 61 employees who are also designated as samples in this study. The research data was obtained by distributing research measuring instruments in the form of questionnaires to employees of the Regional Financial and Asset Management Agency of Bondowoso Regency, totaling 61 employees. The distribution of questionnaires and filling out and returns takes approximately 1 month. Data processing and report preparation takes approximately 2-3 months.

The data analysis technique used in this study is Partial Least Square (PLS) using the WarpPLS 5.0 application. Partial Least Square is a multivariate statistical technique that can handle many response/bound/dependent variables as well as explanatory variables at once (Solihin \& Ratmono, 2013). Based on the variables used in this study consisting of 


\section{GENERAL MANAGEMENT}

independent variables, intervening and dependent variables, the regression equation in this study is as follows: $Y 1=a+b 1 X 1$ $+b 2 X 2+e 1$, and $Y 2=a+b 1 X 1+b 2 X 2+b 3 Z+e 2$.

This outer model analysis is used to specify the relationship between latent variables and their indicators. The tests carried out on the analysis of the outer model are: convergent validity, discriminant validity, composite reliability. The construct reliability test can be measured by 2 (two) criteria, namely composite reliability and Cronbach's alpha. A construct is declared reliable if the composite reliability value is $>0.70$. The reliability test was also strengthened by Cronbach Alpha. Expected Cronbach Alpha value > 0.6 for all constructs. According to (Ghozali, 2016) the expected Average Variance Extracted (AVE) is > 0.5. See and compare between discriminant validity and square root of Average Variance Extracted (AVE). The correlation can be said to be valid if it has a value $>0.5$. If the AVE value is higher than the correlation value between the constructs, then good discriminant validity is achieved. The recommended value is the AVE value must be greater than 0.50 .

Inner model analysis is used to determine the relationship between latent variables. Inner model analysis can be done with path analysis and R Square (R2). Structural path coefficient analysis is used to determine how much influence exogenous variables have on endogenous variables. $R$ Square $(R 2)$ is the coefficient of determination used to see the ability of exogenous variables to explain endogenous variables.

\section{Results and Discussion}

\section{Statistical Analysis Description}

Statistics on the description of employee respondents at the Regional Financial and Asset Management Agency of Bondowoso Regency totaling 61 people related to gender, age and years of service are presented in Table 1.

\begin{tabular}{|l|l|}
\hline Variable & Percentage \\
\hline Sex & \\
\hline Male & 39 \\
\hline Female & 61 \\
\hline Age in years & \\
\hline $20-30$ & 15 \\
\hline $31-40$ & 43 \\
\hline $41-50$ & 30 \\
\hline $51-60$ & 12 \\
\hline Years of service & \\
\hline $0-10$ years & 34 \\
\hline $11-20$ years & 23 \\
\hline $21-30$ years & 33 \\
\hline $31-40$ years & 10 \\
\hline
\end{tabular}

Table 1: Descriptive Statistical Analysis Results

\section{Data Analysis Results}

The validity test criteria is to use the loadings factor (crossloadings factor) with a value of more than 0.50 and average variance extracted (AVE) with a value exceeding 0.50 . To test the validity of the convergent and to test the validity of the discriminant using the ratio of the roots of the AVE with the correlation between variables. The construct AVE value should be higher than the correlation between latent variables (Solihin \& Ratmono, 2013). The results of WarpPLS 5.0 are presented in the Table. 2. The results of the WarpPLS 5.0 calculation in Table 2. show that each value in the cross-loading factor has reached a value above 0.7 with a $p$ value below 0.001 . Thus the convergent validity test criteria have been met. In Table 3, information can be obtained that the AVE root value of the same variable is higher than the AVE root value in different variables. This shows that the discriminant validity test criteria have been met. Thus the instrument used in this study has met all the provisions of the validity test.
Reliability testing is carried out with the aim of ensuring that the research instrument used can provide a consistent measurement of the concept without any bias. The results of the WarpPLS 5.0 data processing for the reliability test are presented in Table 4. The basis used in the reliability test is the value of composite reliability coefficients and Cronbach's alpha coefficients above 0.5 . The results of the reliability test in Table 4. indicate that the questionnaire instrument in this study has met the requirements of the reliability test. The results of hypothesis testing are presented in Table 5. All hypotheses proposed are accepted.

The research model test was conducted to see the suitability of the model built in the study. A good research model will be able to describe the suitability of the relationship between the variables in the study. The use of WarpPLS 5.0 has provided calculation results that show the criteria used to assess whether the model is appropriate. The test results of this research model are presented in Table 6. 


\section{GENERAL MANAGEMENT}

\begin{tabular}{|l|l|l|l|l|l|l|l|}
\hline & $\mathbf{X 1}$ & $\mathbf{X}$ & $\mathbf{X 3}$ & $\mathbf{Y}$ & Type & SE & P value \\
\hline $\mathbf{X 1 . 1}$ & 0.777 & 0.026 & 0.110 & 0.275 & Reflect & 0.101 & $<0.001$ \\
\hline $\mathbf{X 1 . 2}$ & 0.712 & 0.461 & -0.162 & -0.517 & Reflect & 0.100 & $<0.001$ \\
\hline $\mathbf{X 1 . 3}$ & 0.792 & 0.241 & -0.096 & -0.695 & Reflect & 0.104 & $<0.001$ \\
\hline $\mathbf{X 1 . 4}$ & 0.772 & 0.178 & -0.495 & 0.091 & Reflect & 0.105 & $<0.001$ \\
\hline $\mathbf{X 1 . 5}$ & 0.765 & -0.874 & 0.563 & 0.802 & Reflect & 0.101 & $<0.001$ \\
\hline $\mathbf{X 2 . 1}$ & 0.187 & 0.788 & 0.250 & -0.188 & Reflect & 0.101 & $<0.001$ \\
\hline $\mathbf{X 2 . 2}$ & -0.187 & 0.772 & 0.284 & 0.701 & Reflect & 0.101 & $<0.001$ \\
\hline $\mathbf{X 2 . 3}$ & -0.004 & 0.766 & -0.498 & 0.008 & Reflect & 0.102 & $<0.001$ \\
\hline $\mathbf{X 2 . 4}$ & -0.234 & 0.708 & 0.202 & 0.149 & Reflect & 0.104 & $<0.001$ \\
\hline $\mathbf{X 2 . 5}$ & 0.225 & 0.729 & -0.244 & -0.695 & Reflect & 0.103 & $<0.001$ \\
\hline $\mathbf{X 3 . 1}$ & 0.669 & 0.092 & 0.883 & 0.180 & Reflect & 0.124 & $<0.001$ \\
\hline $\mathbf{X 3 . 2}$ & -0.152 & 0.305 & 0.825 & -0.190 & Reflect & 0.096 & $<0.001$ \\
\hline $\mathbf{X 3 . 3}$ & 0.220 & -0.002 & 0.754 & -0.420 & Reflect & 0.098 & $<0.001$ \\
\hline $\mathbf{X 3 . 4}$ & 0.668 & -0.452 & 0.849 & 0.396 & Reflect & 0.126 & $<0.001$ \\
\hline $\mathbf{X 3 . 5}$ & -0.208 & -0.374 & 0.729 & 0.698 & Reflect & 0.103 & $<0.001$ \\
\hline Y1.1 & 0.269 & -0.599 & 0.589 & 0.729 & Reflect & 0.103 & $<0.001$ \\
\hline Y1.2 & -0.288 & -0.717 & 0.580 & 0.766 & Reflect & 0.102 & $<0.001$ \\
\hline Y1.3 & 0.001 & 0.506 & -0.695 & 0.854 & Reflect & 0.121 & $<0.001$ \\
\hline Y1.4 & -0.151 & 0.127 & -0.346 & 0.841 & Reflect & 0.102 & $<0.001$ \\
\hline Y1.5 & 0.219 & 1.272 & -0.783 & 0.746 & Reflect & 0.106 & $<0.001$ \\
\hline
\end{tabular}

Table 2: Combined Loadings and Cross-Loadings

\begin{tabular}{|l|l|l|l|l|}
\hline & $\mathbf{X 1}$ & $\mathbf{X}$ & $\mathbf{X 3}$ & $\mathbf{Y}$ \\
\hline $\mathbf{X 1}$ & 0,7612 & 0,1392 & 0,1382 & $-0,0978$ \\
\hline $\mathbf{X} 2$ & 0,2046 & 0,7716 & 0,0502 & 0,205 \\
\hline $\mathbf{X 3}$ & $-0,064$ & 0,0182 & 0,7644 & 0,0906 \\
\hline $\mathbf{Y}$ & $-0,0308$ & 0,0198 & 0,0112 & 0,7914 \\
\hline
\end{tabular}

Table 3: Comparison of Roots of AVE and Correlation between Variables

\begin{tabular}{|l|l|l|}
\hline Variable & Composite Reliability & Cronbach's Alpha \\
\hline Competence & 0,782 & 0,752 \\
\hline Work Environment & 0,788 & 0,764 \\
\hline Motivation & 0,721 & 0,747 \\
\hline Employee Performnce & 0,769 & 0,724 \\
\hline
\end{tabular}

Table 4: Reliability Test Results

\begin{tabular}{|l|l|l|l|l|}
\hline & Hypothesis & $\begin{array}{l}\text { Path } \\
\text { Coefficients }\end{array}$ & $\begin{array}{l}\text { P- } \\
\text { value }\end{array}$ & Conclusion \\
\hline H1 & Employee competence affects motivation & 0,214 & 0,039 & $\begin{array}{l}\text { Hypothesis } \\
\text { Accepted }\end{array}$ \\
\hline H2 & The work environment affects motivation & 0,588 & 0,001 & $\begin{array}{l}\text { Hypothesis } \\
\text { Accepted }\end{array}$ \\
\hline H3 & $\begin{array}{l}\text { Employee competence affects employee } \\
\text { performance }\end{array}$ & 0,249 & 0.019 & $\begin{array}{l}\text { Hypothesis } \\
\text { Accepted }\end{array}$ \\
\hline H4 & $\begin{array}{l}\text { The work environment affects employee } \\
\text { performance }\end{array}$ & 0,630 & 0,001 & $\begin{array}{l}\text { Hypothesis } \\
\text { Accepted }\end{array}$ \\
\hline H5 & $\begin{array}{l}\text { Work motivation affects employee } \\
\text { performance }\end{array}$ & 0,220 & 0,031 & $\begin{array}{l}\text { Hypothesis } \\
\text { Accepted }\end{array}$ \\
\hline
\end{tabular}

Table 5: Recapitulation of Hypothesis Test Results 


\section{GENERAL MANAGEMENT}

\begin{tabular}{|l|l|l|}
\hline Information & Value & Ideal \\
\hline Average path coefficient (APC) & $\mathrm{P} 0.001$ & $<=0,05$ \\
Average R-squared (ARS) & $\mathrm{P} 0.001$ & $<=0,05$ \\
Average adjusted R-squared (AARS) & $\mathrm{P} 0.001$ & $<=0,05$ \\
Average block VIF (AVIF) & 1,467 & $<=3,3$ \\
Average full collinearity VIF (AFVIF) & 2,096 & $<=3,3$ \\
Tenenhaus GoF (GoF) & 0.448 & besar \\
Sympson's paradox ratio (SPR) & 1 & 1 \\
R-squared contribution ratio (RSCR) & 1 & 1 \\
Statistical suppression ratio (SSR) & 1 & $>=0,7$ \\
Nonlinear bivariate causality direction ratio (NLBCDR) & 1 & $>=0,7$ \\
& & \\
\hline
\end{tabular}

Table 6: Research Model Test

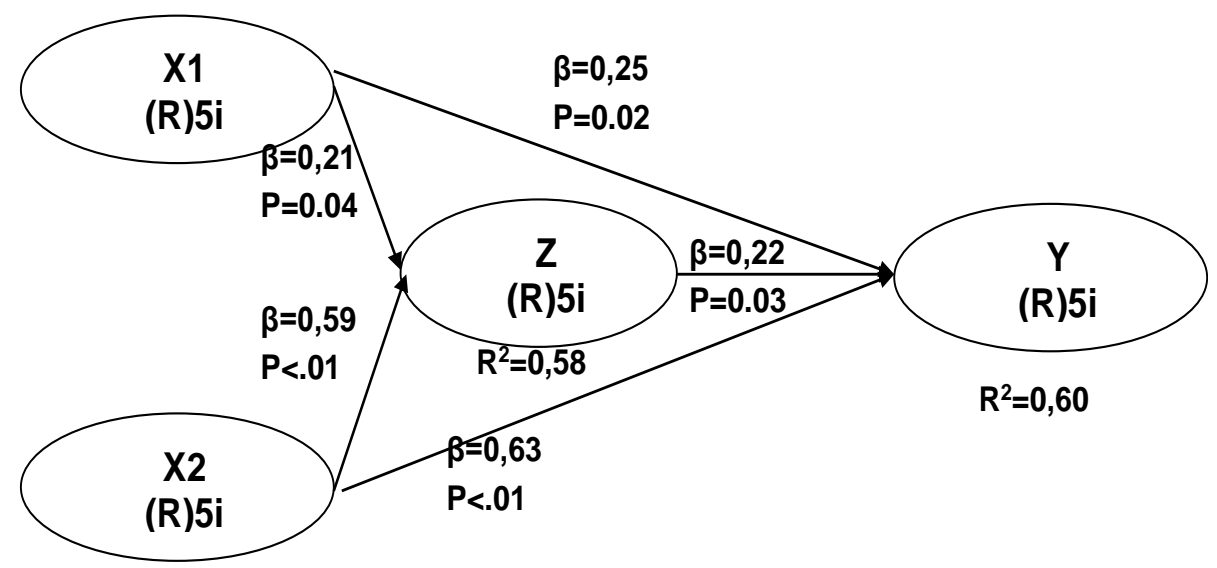

Figure 2: Path Analysis Results

Based on Table 6. it can be seen that each value in the study has met the ideal criteria. The values of APC, ARS, and AVIF that meet the ideal criteria indicate that the overall research model is good. The fit of the model can also be calculated using the goodness of fit index. The goodness of fit index (GoF) is defined as the geometric mean or root of the average communality and the average R2 for all endogenous constructs. The GoF index shows the predictive power of the overall model. The GoF value has an interval between 0 to 1 . A GoF value close to 1 indicates a good path model estimation. The GoF

The results of the analysis of the influence of employee competence and work environment on work motivation, show the coefficient of determination or R2 of 0.579 , from these results it means that all independent variables (employee competence and work environment) have a contribution of $57.9 \%$ to the dependent variable (work motivation). , and the remaining $42.1 \%$ is influenced by other factors not included in the study. The results of the analysis of the influence of employee competence, work environment and work motivation on employee performance, show the coefficient of determination or $\mathrm{R}$ square of 0.596 , from these results it means that all independent variables (employee competence, work environment and work motivation) have a contribution of $59.6 \%$ on the dependent variable (employee performance), and the remaining $40.4 \%$ is influenced by other factors not included in the study. The higher the R2 value, the better the prediction model of the proposed model. (Ghozali, 2016) states that in general the coefficient of determination is low if it is worth 0.20 , while in the results of this model the two coefficients are worth more than 0.20 . index for this research model is 0.448 . Thus, the structural model that explains the relationship between the four variables has a good predictive power (fit).

Hypothesis testing is based on the results of the analysis of the PLS SEM model which contains all the variables supporting the hypothesis test. The PLS model with the addition of work motivation variables as mediating variables explains that the addition of variables will provide additional contributions as an explanation of employee performance. The results of the path analysis in this study can be seen in Figure 2.

\section{Discussion}

Based on the results of testing the employee competence variable on employee performance, the coefficient value is 0.249 with an -value of 0.019 . Because the value of -value is smaller than $(0.019<0.05)$, then $\mathrm{HO}$ is rejected, thus there is a significant effect of employee competence on employee performance. This means that employee competence has a significant effect on the performance of employees of the Regional Financial and Asset Management Agency of Bondowoso Regency. Thus the hypothesis which states that competence affects employee performance is proven true or $\mathrm{H} 1$ is accepted.

Based on the results of testing the work environment variable on employee performance, the coefficient value is 0.630 with an -value of 0.001 . Because the -value is smaller than $(0.001<0.05)$ then $\mathrm{HO}$ is rejected, thus there is a significant effect of the work environment on employee performance, based on the second hypothesis which states that the work environment affects employee performance. This means that the work environment has a significant effect on the performance of the employees of the Regional Financial and 
Asset Management Agency of Bondowoso Regency.

Based on the results of testing the work motivation variable on employee performance, the coefficient value is 0.220 with an -value of 0.031 . Because the value of -value is smaller than $(0.031<0.05)$, then $\mathrm{H} 0$ is rejected, thus there is a significant effect of work motivation on employee performance. This means that work motivation has a significant effect on the performance of employees of the Regional Financial and Asset Management Agency of Bondowoso Regency, which is proven true or $\mathrm{H} 3$ is accepted. Motivation is an encouragement so that someone is motivated in doing work to be better (Mangkunegara, 2010). By having a strong motivation in order to get an award from the organization, it is possible that an employee will improve his performance.

\section{Conclusions, Suggestions and Limitations}

Based on the research findings that have been described, the conclusions in this study are as follows: (1) the test results prove employee competence, has a positive and significant effect on work motivation and employee performance at the Regional Financial and Asset Management Agency of Bondowoso Regency. Employee competence is the expertise possessed by employees in carrying out their duties. The better the competencies possessed by employees, the greater the confidence they will be able to complete the work, thereby increasing employee motivation at work. Successful employees who have high motivation at work are usually also able to complete work on time which means their performance is good; (2) The test results prove that the work environment has a positive and significant effect on work motivation and performance of employees of the Regional Financial and Asset Management Agency of Bondowoso Regency. The work environment used to work must be made as comfortable as possible so that employees are motivated to complete their work on time. Work that can be completed on time indicates that employees have provided good performance for the institution

\section{References}

[1] Rahmisyari, R. (2017). Pengaruh Kompetensi dan Lingkungan Kerja Terhadap Kinerja Pegawai. Jurnal Manajemen Dan Bisnis Indonesia, 5(1), 48-61. doi:10.31843/jmbi.v5i1.139

[2] Effect of motivation, competence and Islamic leadership on job satisfaction and Teacher performance in vocational high school

[3] Achmad, S. H. (2017). THE EFFECT OF COMPETENCY, MOTIVATION, AND ORGANIZATIONAL CULTURE ON THE EMPLOYEE PERFORMANCE AT THE JAYAKARTA HOTEL, BANDUNG, INDONESIA. Journal of Business on Hospitality and Tourism, 2(1), 120. doi:10.22334/jbhost.v2i1.48

[4] Adam, F., \& Kamase, J. (2019). The effect competence and motivation to satisfaction and performance. International Journal of Scientific and Technology Research, 8(3), 132-140.

[5] Adha, R. N., Qomariah, N., \& Hafidzi, A. H. (2019). Pengaruh Motivasi Kerja, Lingkungan Kerja, Budaya Kerja Terhadap Kinerja Karyawan Dinas Sosial Kabupaten Jember. Jurnal Penelitian IPTEKS, 4(1), 47. doi:10.32528/ipteks.v4i1.2109

[6] Ahmad, M. A., Talib, B., \& Tiro, M. A. (2014). The Influence Of Certification Toward Work Motivation, Job Satisfaction And Performance Of State High Schools Guidance And Counseling Teacher In South Sulawesi. International Journal of Scientific and Technology Research, 3(8), 386-394. https://www.ijstr.org/finalprint/aug2014/The-Influence-Of-Certification-Toward-WorkMotivation-Job-Satisfaction-And-Performance-Of-State-HighSchools-Guidance-And-Counseling-Teacher-In-SouthSulawesi.pdf

[7] Aktarina, D. (2015). Pengaruh Karakteristik Individu, Pekerjaan where they work; (3) work motivation affects the performance of employees of the Regional Financial and Asset Management Agency of Bondowoso Regency. Employees who are motivated to work well will be able to improve performance at the institution where they work.

The suggestions that can be given based on the results of the study are: (1) Referring to the results of the study that the work environment has the strongest influence on improving employee performance, it is hoped that the Bondowoso Regency BPKAD will further improve the work environment at the Regional Financial and Asset Management Agency of Bondowoso Regency, both physically and non-physically. For other researchers, it is advisable to examine the effect of the work environment not only physically, but also non-physically. (2) For other researchers, it is recommended to consider the measurement scale that will be used in the research questionnaire, so that respondents who do not understand the question or questionnaire statement do not answer neutrally or do not have an opinion. (3) For future research, it is recommended to consider other factors that also affect work motivation and employee performance such as leadership, work environment and work discipline. (4) Subsequent research in order to expand the orientation of the research to a larger scope of organization or a larger population so that the level of generalization is higher.

Every research conducted will never be perfect, because there must be limitations in the implementation of the research. The limitations of this study are: (1) this research was only conducted within the Regional Financial and Asset Management Agency of Bondowoso Regency, where the total population was only 61 employees; (2) the work environment variables studied were only limited to the physical environment, even though there were non-physical work environments which were actually more substantive in increasing work motivation and employee performance; (3) the research was conducted in the midst of the Covid-19 pandemic which caused the completion time of this research to be longer due to the WFH (Work From Home) policy from the Government.

Dan Lingkungan Kerja Terhadap Motivasi Dan Dampaknya Terhadap Kinerja Anggota Polri Di Polresta Palembang. Jurnal Media Wahana Ekonomika, 12(3), 42-54.

[8] Amdani, D., Sinulingga, S., Absah, Y., \& Muda, I. (2019). The effect of competence and organizational culture on employee performance of ganesha medan polytechnic. International Journal of Scientific and Technology Research, 8(4), 155-159.

[9] Anggitaningsih, R., \& Handriyono, H. (2019). Effect Of Environmental Work Leadership Style Compensation On Employee Productivity Intervening As Employee Satisfaction In Business Unit Pt. Brantas Bipraya In Jakarta. International Journal of Scientific and Technology Research, 8(7), 182-189.

[10] Ardianti, F. E., Qomariah, N., \& Wibowo, Y. G. (2018). PENGARUH MOTIVASI KERJA, KOMPENSASI DAN LINGKUNGAN KERJA TERHADAP KEPUASAN KERJA KARYAWAN (Studi Kasus Pada PT. Sumber Alam Santoso Pratama Karangsari Banyuwangi). Jurnal Sains Manajemen Dan Bisnis Indonesia, 8(1). doi:10.32528/smbi.v8i1.1764

[11] Ariono, I. (2017). ANALISA PENGARUH TINGKAT PENDIDIKAN, MASA KERJA DAN MOTIVASI KERJA TERHADAP KINERJA PERANGKAT DESA DI KECAMATAN KALIWIRO WONOSOBO. Jurnal Penelitian Dan Pengabdian Kepada Masyarakat UNSIQ, 4(3), 254-267. doi:10.32699/ppkm.v4i3.430

[12] Ataunur, I., \& Ariyanto, E. (2016). Pengaruh Kompetensi dan Pelatihan terhadap Kinerja Karyawan PT. Adaro Energy Tbk. Telaah Bisnis, 16(2). doi:10.35917/tb.v16i2.33

[13] Atikah, K., \& Qomariah, N. (2020). The effect of leadership style, 
organizational culture and motivation on employee performance. Jurnal Manajemen dan Bisnis Indonesia, 6(2), 216-227. https://doi.org/10.5267/j.msl.2020.2.008

[14] Azhad, M. N., Anwar, \& Qomariah, N. (2015). Manajemen Sumber Daya Manusia. Cahaya IImu.

[15] Bahri, S., Basalamah, S., Kamse, J., \& Bijang, J. (2018). The effect of islamic leadership, competence and compensation on work dicipline and teacher performance of madrasah aliyah in makassar city. International Journal of Scientific and Technology Research, 7(12), 137-143.

[16] Basalamah, M. S. (2017). The Influence Of Motivation, Competence And Individual Characteristics On Performance Clerk (The Study) In The City Of Makassar. International Journal of Scientific \& Technology Research, 6(12), 148-153.

[17] Basriani, A. (2016). Pengaruh kompetensi dan komitmen organisasi terhadap kepuasan kerja dan kinerja dosen ( studi pada yayasan pendidikan persada bunda pekanbaru). Tepak Manajemen Bisnis, VIII(1), 21-34.

[18] Bentar, A., Purbangkoro, M., \& Prihartini, D. (2017). ANALISIS PENGARUH KEPEMIMPINAN, MOTIVASI, DISIPLIN KERJA DAN LINGKUNGAN KERJA TERHADAP KINERJA KARYAWAN TAMAN BOTANI SUKORAMBI ( TBS ) JEMBER. Jurnal Manajemen dan Bisnis Indonesia, 3(1), 1-17.

[19] Brahmasari, I. A., \& Suprayetno, A. (2008). Pengaruh Motivasi Kerja , Kepemimpinan dan Budaya Organisasi Terhadap Kepuasan Kerja Karyawan serta Dampaknya pada Kinerja Perusahaan ( Studi kasus pada PT. Pei Hai International Wiratama Indonesia ). Jurnal Manajemen dan Kewirausahaan, 10(2), 124-135.

[20] Brury, M. (2016). Pengaruh Kepemimpinan, Budaya Organisasi, Motivasi Kerja Dan Kepuasan Kerja Terhadap Kinerja Pegawai Pada Kantor SAR Sorong. Jurnal Riset Bisnis Dan Manajemen, 4(1), 1-16.

[21] Chandra, J. A., G, N. N. P. M., \& Qomariah, N. (2020). Impact of Organizational Citizenship Behavior, Leadership , Individual Characteristics and Competence on Teacher Performance. Jurnal Manajemen dan Bisnis Indonesia, 6(2), 244-256.

[22] Changgriawan, G. S. (2017). Pengaruh Kepuasan Kerja dan Motivasi Kerja Terhadap Kinerja Karyawan One Way Production. $\begin{array}{lll}\text { Jurnal } \quad \text { Agora, } & \text { 5(3), }\end{array}$ http://publication.petra.ac.id/index.php/manajemenbisnis/article/view/6095/5593

[23] Dessy, Yunita, L., \& Sinulingga, N. A. B. (2018). Pengaruh Karakteristik Individu Dan Lingkungan Kerja Terhadap Kinerja Karyawan Pada PT. Perkebunan Nusantara II Pagar Merbau Dessy1,. Journal of Management Science (JMAS), 1(1), 1-6.

[24] Dolphina, E. (2012). Pengaruh Motivasi, Kepemimpinan Dan Budaya Kerja Terhadap Kepuasan Kerja Karyawan Serta Dampaknya Pada Kinerja Perusahaan. Seminar Nasional Teknologi Informasi \& Komunikasi Terapan 2012 (Semantik 2012), 2012(Semantik), 1-7. http://publikasi.dinus.ac.id/index.php/semantik/article/view/220/2 32

[25] Fachreza, Musnadi, S., \& Majid, M. S. A. (2014). Pengaruh Motivasi kerja, lingkungan kerja, dan budaya organisasi terhadap kinerja karyawan dan dampaknya pada kinerja Bank Aceh Syariah di Kota Banda Aceh. Jurnal Magister Manajemen, V(1), 42-56.

https://www.google.com/url?sa=t\&rct=j\&q=\&esrc=s\&source=we $\mathrm{b} \& \mathrm{~cd}=1 \& \mathrm{cad}=\mathrm{rja} \&$ uact $=8 \&$ ved $=2 \mathrm{ahUKEwiHnMrM7dvjAhWKpl8}$ KHZ8FD2gQFjAAegQIAxAC\&url=http\%3A\%2F\%2Fjournal.umy. ac.id\%2Findex.php\%2Fbti\%2Farticle\%2Fdownload\%2F2451\%2 F2431\&usg=AOvVaw2eWz9IL0SzjcSKDquKhp8z

[26] Feel, N. H., Herlambang, T., \& Rozzaid, Y. (2018). Pengaruh Disiplin Kerja, Budaya Organisasi Dan Lingkungan Kerja Terhadap Kinerja Pegawai. Penelitian Ipteks, 3(2), 176-185.

[27] Firdaus, F., Widyanti, R., \& Khuzaini, K. (2017). PENGARUH MOTIVASI DAN LINGKUNGAN KERJA TERHADAP KINERJA KARYAWAN. AI-KALAM JURNAL KOMUNIKASI, BISNIS DAN MANAJEMEN, 4(1), 86. doi:10.31602/al-kalam.v4i1.830
[28] Friolina, D. G., Sudarsih, S., Endhiarto, T., \& Musmedi, D. P. (2017). Do Competence, Communication , And Commitment Affect The Civil Servants Performance? International Journal of Scientific \& Technology Research, 6(09), 211-215.

[29] Gala, I. N., Ramadhan, H. A., \& Rede, A. (2017). Pengaruh Pelatihan dan Motivasi Kerja Terhdap Kinerja Mengajar Guru IPA di SMP Se-Kota Poso. Mitra Sains, 5(2), 58-66.

[30] Ghozali, I. (2013). Aplikasi Analisis Multivariat dengan Program IBM SPSS 21 Update PLS Regresi . . BP Universitas Diponegoro.

[31] Ghozali, I. (2016). Aplikasi Analisis Multivariete Dengan Program IBM SPSS 23. In Universitas Diponegoro (Edisi 8). https://doi.org/https://doi.org/10.3929/ethz-b-000238666

[32] Hafifi, M. A., Qomariah, N., \& Anwar, A. (2018). PENINGKATAN KINERJA BERBASIS LINGKUNGAN KERJA, GAYA KEPEMIMPINAN, DAN PELATIHAN KERJA PADA KARYAWAN BAGIAN PRODUKSI PT. MITRATANI DUA TUJUH JEMBER. JURNAL MANAJEMEN DAN BISNIS INDONESIA, 4(1). doi:10.32528/jmbi.v4i1.1715

[33] Hanafi, C., \& Sanosra, A. (2018). PENGARUH MOTIVASI KERJA, IKLIM ORGANISASI TERHADAP KOMITMEN ORGANISASI DAN KINERJA DOSEN PENDIDIKAN GURU PENDIDIKAN ANAK USIA DINI IKIP PGRI JEMBER. Jurnal Sains Manajemen Dan Bisnis Indonesia, 8(1). doi:10.32528/smbi.v8i1.1769

[34] Hardianto, A., Riadi, S. S., Mintarti, S., Hariyadi, S., Hutauruk, M. R., \& Ghozali, I. (2020). The Impact Of Human Relations On Motivation And Performance And The Role Of Entrepreneur Mediators In Bank Mandiri (Persero) Tbk East Kalimantan Kaltara Areas. International Journal of Scientific and Technology Research, 9(3), 1238-1243.

[35] Hasibuan, E. A., \& Afrizal. (2019). ANALISIS PENGARUH KOMPETENSI, LINGKUNGAN KERJA, DAN KOMPENSASI TERHADAP KEPUASAN KERJA DAN IMPLIKASINYA TERHADAP KINERJA APARATUR SIPIL NEGARA Erni. JEM: Jurnal Ekonomi dan Manajemen STIE Pertiba Pangkalpinang, $5(1), 22-41$.

[36] Hasibuan, M. S. P. (2016). Manajemen Sumber Daya Manusia: Edisi Revisi. Bumi Aksara.

[37] Hendrawijaya, A. T., Imsiyah, N., \& Indrianti, D. T. (2019). Public servants characteristics and their perception on motivation and performance. International Journal of Scientific and Technology Research, 8(6), 78-81. https://www.ijstr.org/finalprint/june2019/Public-Servants-Characteristics-And-TheirPerception-On-Motivation-And-Performance-.pdf

[38] Herawati, \& Mahfudnurnajamuddin. (2018). Pengaruh kompetensi, disiplin dan iklim organisasi terhadap kinerja pegawai pada balai besar pelaksanaan jalan nasional $\mathrm{vi}$ kementrian pekerjaan umum makassar. PARADOKS Jurnal IImu Ekonom, 1.

[39] Hermawan, H. (2015). PENGARUH MOTIVASI KERJA, KOMPENSASI FINANSIAL DAN KOMPENSASI NON FINANSIAL TERHADAP PRESTASI KERJA KARYAWAN PADA PERUSAHAAN BINTANG MULIA HOTEL \& RESTO JEMBER. Jurnal Manajemen dan Bisnis Indonesia, 1(2), 143-161.

[40] Hidayah, T., \& Tobing, D. S. K. (2018). The influence of job satisfaction, motivation, and organizational commitment to employee performance. International Journal of Scientific and Technology Research, 7(7), 122-127. https://www.ijstr.org/finalprint/july2018/The-Influence-Of-Job-Satisfaction-Motivation-AndOrganizational-Commitment-To-Employee-Performance.pdf

[41] Husnah, L., Setyowati, T., \& S, W. E. (2018). PENGARUH PELATIHAN KERJA, LINGKUNGAN KERJA DAN KOMITMEN ORGANISASI TERHADAP KINERJA KARYAWAN DI ROYAL HOTEL JEMBER. JURNAL MANAJEMEN DAN BISNIS INDONESIA, 4(1). doi:10.32528/jmbi.v4i1.1714

[42] Hutapea, T. (2008). Kompetensi Pluss. Gramedia Pustaka Utama.

[43] Indiyaningsih, K. M. H., Murdyastuti, A., \& Puspitaningtyas, Z. (2020). Efeect of human resource competency, work culture and utilization of information technology to performance of 
employees. International Journal of Scientific and Technology Research, 9(4), 3636-3641.

[44] Indris, S., \& Primiana, I. (2015). Internal And External Environment Analysis On The Performance Of Small And Medium Industries Smes In Indonesia. International Journal of Scientific \& Technology Research, 4(4), 188-196.

[45] Iskandar, S., \& Juhana, E. (2014). Pengaruh Kompetensi Dan Lingkungan Kerja Terhadap Kepuasan Kerja Serta Implikasinya Pada Kinerja Guru Di SDN Baros Mandiri 5 Kota Cimahi. Jurnal Ekonomi, Bisnis \& Entrepreneurship, 8(2), 86-98. http://jurnal.stiepas.ac.id/index.php/jebe/article/view/41

[46] Istanti, E., Gs, A. D., Budianto, F., Noviandari, I., \& Sanusi, R. (2020). The influences of motivation, work milieu, and organizational commitment on teacher performance in MTS Negeri 4 (Public Islamic School), Surabaya East Java. International Journal of Innovation, Creativity and Change, 13(2), 629-642.

[47] Julianry, A., Syarief, R., \& Affandi, M. J. (2017). Pengaruh Pelatihan dan Motivasi Terhadap Kinerja Karyawan serta Kinerja Organisasi Kementerian Komunikasi dan Informatika. Jurnal Aplikasi Bisnis Dan Manajemen. doi:10.17358/jabm.3.2.236

[48] Kapahang, J. O., Kojo, C., \& Uhing, Y. (2014). Pendidikan, Pengalaman Kerja Dan Kompetensi Pengaruhnya Terhadap Kinerja Karyawan Pada Pt. PIn (Persero) Wilayah Suluttenggo. Jurnal EMBA, 2(4), 503-513. http://www.spectrumgroupe.fr/product/microsoft-teams/

[49] Komaling, H. J., Adolfina, \& Untu, V. (2016). The Influences Of Recruitment, Motivation, And Work Environment To The Employee Performance Of PT . Bank Rakyat. Jurnal Berkala IImiah Efisiensi, 16(01), 738-749.

[50] Koni, W. (2018). Pengaruh Tingkat Pendidikan Dan Motivasi Kerja Terhadap Kinerja Dosen lain Sultan Amai Gorontalo. AlBuhuts, 14(01), 53-72. doi:10.30603/ab.v14i01.418

[51] Kosasih, A. (2018). Pengaruh Kepemimpinan Transformasional, Budaya Organisasi dan Motivasi Kerja Pegawai terhadap Kepuasan Kerja Pegawai serta Implikasinya pada Kinerja Pegawai PDAM di Propinsi Banten. Journal of Government and Civil Society, 1(2), 159. doi:10.31000/jgcs.v1i2.442

[52] Kurniawan, R. A., Qomariah, N., \& Winahyu, P. (2019). Dampak Organizationlal Citizenship Behavior, Motivasi Kerja, Dan Kepuasan Kerja Terhadap Kinerja Karyawan. Jurnal Penelitian IImu Manajemen, 4(4), 148-160.

[53] Kurniawati, D., \& Tobing, D. L. S. (2019). The effect of motivation, working environment, and self leadership on lecturer performance at politeknik negeri jember. International Journal of Scientific and Technology Research, 8(7), 820-825.

[54] Lopes, E. da C. (2016). Pengaruh Motivasi Terhadap Disiplin Kerja Dan Kinerja Pegawai Pada Direccao Geral Dos Servicos Corporativos Ministerio Das Obras Publicas Dili Timor-Leste. Jurnal Sains Manajemen \& Bisnis Indonesia, 6(2), 158-169.

[55] Luthans, F. (1995). Organizational behavior (7th ed.). McGrawHill, Inc.

[56] Mananeke, L., Mandey, S., \& Mufidah, M. (2014). Analisis Tingkat Pendidikan, Kompetensi Dan Kompensasi Terhadap Kinerja Karyawan Pada Pt. Asuransi Jasaraharja Putera Manado. Jurnal Riset Ekonomi, Manajemen, Bisnis dan Akuntansi, 2(2), 13391348. https://doi.org/10.35794/emba.v2i2.4726

[57] Manggis, I. W., Yuesti, A., \& Sapta, I. K. S. (2018). The Effect of Career Development and Organizational Culture to Employee Performance with Motivation of Work as Intervening Variable in Cooperation in Denpasar Village. International Journal of Contemporary Research and Review, 9(07), 20901-20916. doi:10.15520/ijcrr/2018/9/07/553

[58] Mangkunegara, A. A. P. (2010). Manajemen Sumber Daya Manusia, Cetakan Kedua. PT Remaja Rosdakarya.

[59] Manik, E., \& Wiarah. (2014). Pengaruh Kompetensi Dan Kompensasi Terhadap Kepuasan Kerja Serta Implikasinya Pada Kinerja Paramesia Di Rumah Sakit Cibabat Kota Cimahi. Jurnal Ekonomi, Bisnis \& Entrepreneurship, 8(2), 62-72. http://jurnal.stiepas.ac.id/index.php/jebe/article/view/39
[60] Manik, S., \& Syafrina, N. (2018). PENGARUH KOMPETENS TERHADAP KINERJA DOSEN SEKOLAH TINGGI ILMU EKONOMI RIAU. Jurnal IImiah Ekonomi Dan Bisnis, 15(1), 1-6. doi:10.31849/jieb.v15i1.72

[61] Marhayani et al. (2019). Effect of Competence and Employee Commitment To Employee Performance: Job Satisfaction As a Mediator (Study on Watering Office of Aceh Province). International Journal of Business Management and Economic Review, 2(1), 15-27. http://ijbmer.org/uploads2019/BMER_2_75.pdf

[62] Marwanto, T. B., \& Nugroho, R. (2014). Pengaruh Kompensasi Dan Lingkungan Kerja Terhadap Motivasi Dan Disiplin Kerja Prajurit Di Satuan Kerja KRI X Armada RI Kawasan Timur. Jurnal IImu Ekonomi \& Manajemen, 1(1), 74-82. http:/jurnal.untagsby.ac.id/index.php/jmm17/article/view/313/347

[63] Mayangsari, L., Restianti, T., Saputra, J., \& Rahadi, R. A. (2020). The relationship between self-employed motivation and individual work performance among online drivers in West Java, Indonesia. International Journal of Innovation, Creativity and Change, 13(3), 513-530.

https://www.jicc.net/images/vol_13/lss_3/13373_Mayangsari_2 020 E R.pdf

[64] Meidita, A. (2019). Pengaruh Pelatihan dan Kompetensi Terhadap Kepuasan Kerja Melalui Motivasi Kerja. Maneggio: Jurnal IImiah Magister Manajemen, 2(2), 226-237. doi:10.30596/maneggio.v2i2.3772

[65] Mu'ah, M. (2002). Manajemen Sumber Daya Manusia. Grasindo.

[66] Arifin, H. M. (2014). The Influence of Competence, Motivation, and Organisational Culture to High School Teacher Job Satisfaction and Performance. International Education Studies, 8(1). doi:10.5539/ies.v8n1p38

[67] Mukhtar, A. (2018). The effect of competence and organization culture to work satisfaction and employee performance of Sharia banks in Makassar city. International Journal of Scientific and Technology Research, 7(10), 1-6.

[68] Mulyadi. (2016). Manajemen Sumber Daya Manusia. IN Media.

[69] Mustikawati, E., \& Qomariah, N. (2020). The Effect of Education Training and Competency on Teacher Performance. International Journal of Business and Management Invention (IJBMI), 9(10), 14-20. https://doi.org/10.35629/80280910031420

[70] Ngattemin, \& Arumwati, W. (2012). PENGARUH KOMPETENSI DAN KOMPENSASI TERHADAP MOTIVASI KERJA KARYAWAN HOTEL DI KABUPATEN KARO PROVINSI SUMATERA UTARA. Jurnal Riset Akuntansi dan Bisnis, 12(September), 80-92.

[71] Nitisemito, A. S. (2008). Manajemen Personalia (MSDM). Ghalia.

[72] Novitasari, A., Wahyudin, A., \& Setiyan, R. (2012). Pengaruh Kepemimpinan Kepala Sekolah, Lingkungan Kerja, Pendidikan, Dan Pelatihan Terhadap Kinerja Guru. Economic Education Analysis Journal, 1(2).

[73] Nyoto, Purwati, A. A., \& Suyono. (2020). A study on the influence of organizational culture, leadership, transformational leadership, and compentency on the commitment of DPRD members and the implication to the performance of the regency/municipal DPRD members in Riau Province. International Journal of Scientific and Technology Research, 9(4), 596-605.

[74] PAAIS, M., \& PATTIRUHU, J. R. (2020). Effect of Motivation, Leadership, and Organizational Culture on Satisfaction and Employee Performance. The Journal of Asian Finance, Economics and Business, 7(8), 577-588 doi:10.13106/jafeb.2020.vol7.no8.577

[75] PANCASILA, I., HARYONO, S., \& SULISTYO, B. A. (2020). Effects of Work Motivation and Leadership toward Work Satisfaction and Employee Performance: Evidence from Indonesia. The Journal of Asian Finance, Economics and Business, 7(6), 387-397. doi:10.13106/jafeb.2020.vol7.no6.387

[76] Parhusip, A. A., Alamsyah, V., \& Rahman, M. F. (2020). PENGARUH SEMANGAT KERJA, KEJELASAN PERAN, FISIK LINGKUNGAN KERJA TERHADAP KINERJA PEGAWAI DI 
UNIVERSITAS POTENSI UTAMA. Accumulated Journal, 2, 114.

[77] Perdana, A. H. (2018). Pengaruh Kompetensi Budaya Organisasi dan Motivasi Terhadap Kinerja Dosen Perguruan TInggi Swasta di Kota Makassar. doi:10.31219/osf.io/67n8g

[78] Permana, A., Aima, M. H., Ariyanto, E., \& Nurmahdi, A. (2019). The effect of leadership style, motivation and discipline of employee performance with understanding of islamic work ethics. International Journal of Scientific and Technology Research, 8(8), 1098-1106. https://www.ijstr.org/final-print/aug2019/The-EffectOf-Leadership-Style-Motivation-And-Discipline-Of-EmployeePerformance-With-Understanding-Of-Islamic-Work-Ethics.pdf

[79] Pinca, E. C. (2015). The Mobile Teachers Profile Competencies Performance And Problems In The Department Of Education Division Of Northern Samar Philippines. International Journal of Scientific \& Technology Research, 4(8), 45-50.

[80] Pioh, N. L., \& Tawas, H. N. (2016). Pengaruh Kompensasi dan Lingkungan Kerja terhadap Kepuasan Kerja dan Kinerja Pegawai (Studi Pada PNS Di Kantor Kecamatan Sonder Kabupaten Minahasa ). Jurnal EMBA, 4(2), 838-848.

[81] Prahiawan, W., Sultan, U., \& Tirtayasa, A. (2017). PENGARUH KOMPETENSI KARYAWAN DAN LINGKUNGAN KERJA TERHADAP KINERJA KARYAWAN MELALUI MOTIVASI KERJA SEBAGAI VARIABEL INTERVENING (Studi Pada PT. Krakatau Bandar Samudera). Jurnal Riset Bisnis dan Manajemen Tirtayasa mempengaruhi, 1(2), 149-158. https://jurnal.untirta.ac.id/index.php/JRBM/article/view/3149/239 3

[82] Prakoso, R. D., Astuti, E. S., \& Ruhana, I. (2014). PENGARUH LINGKUNGAN KERJA TERHADAP MOTIVASI KERJA DAN KINERJA KARYAWAN (Studi Pada Karyawan PT. AXA Financial Indonesia Cabang Malang). Jurnal Administrasi Bisnis (JAB), 14(2), $1-10$. http://administrasibisnis.studentjournal.ub.ac.id/index.php/jab/art icle/view/596/795

[83] Prijono, W. P., Cahyono, D., \& Qomariah, N. (2019). Usaha Meningkatkan Kinerja Pegawai SKPD ( Satuan Kerja Pemerintah Daerah ) Di Lingkungan Inspektorat Kabupaten Jember. 9(1), 20 33.

[84] Priyono, B. H., Qomariah, N., \& Winahyu, P. (2018). PENGARUH GAYA KEPEMIMPINAN, MOTIVASI GURU DAN LINGKUNGAN KERJA FISIK TERHADAP KINERJA GURU SMAN 1 TANGGUL JEMBER. JURNAL MANAJEMEN DAN BISNIS INDONESIA, 4(2), 144. doi:10.32528/jmbi.v4i2.1758

[85] Priyono, B. H., Qomariah, N., \& Winahyu, P. (2018b). PENGARUH GAYA KEPEMIMPINAN, MOTIVASI GURU DAN LINGKUNGAN KERJA FISIK TERHADAP KINERJA GURU SMAN 1 TANGGUL JEMBER. JURNAL MANAJEMEN DAN $\begin{array}{lll}\text { BISNIS INDONESIA, } & 4(2), & \end{array}$ https://doi.org/10.32528/jmbi.v4i2.1758

[86] Pujiarti. (2019). Pengaruh Kompetensi Dan Kompensasi Terhadap Kinerja Karyawan Dengan Kepuasan Kerja Sebagai Variabel Intervening Pada PT. Pilar Guna Usahatama. PRIMANOMICS : JURNAL EKONOMI DAN BISNIS -, 1, 1-14.

[87] Qomariah, N., Hermawan, H., Isnaini, N. H., \& Naely Azhad, M. (2020). How to Improve Employee Performance at Level 1 Health Facilities During the Covid 19 Pandemic? International Journal of Engineering Research and Technology, 13(9), 2511. doi:10.37624/ijert/13.9.2020.2511-2518

[88] Qomariah, N., Warsi, W., \& Sanosra, A. (2020). How to Improve Vocational Teacher Performance?

[89] Rahim, A., Syech, S., \& MS, M. Z. (2017). PENGARUH LINGKUNGAN KERJA DAN KOMPETENSI TERHADAP MOTIVASI KERJA SERTA DAMPAKNYA TERHADAP KINERJA PEGAWAI PADA DINAS PENDIDIKAN KABUPATEN TANJUNG JABUNG TIMUR. J-MAS (Jurnal Manajemen Dan Sains), 2(2), 133. doi:10.33087/jmas.v2i2.25

[90] Rande, D. (2016). Pengaruh kompetensi terhadap kinerja pegawai pada dinas perhubungan, komunikasi dan informatika kabupaten mamuju utara. e Jurnal Katalogis, 4, 101-109.
[91] Renyut, B., Modding, H. B., Bima, J., \& Sukmawati, S. (2017). The effect of organizational commitment, competence on Job satisfaction and employees performance in Maluku Governor's Office. IOSR Journal of Business and Management, 19(11), 1829. https://doi.org/10.31227/osf.io/hnwdt

[92] Riansari, T., Sudiro, A., \& Rofiaty. (2012). Pengaruh Kompensasi dan Lingkungan Kerja terhadap Kepuasan Kerja dan Kinerja Karyawan ( Studi Kasus PT Bank TabunganPensiunan Nasional , TbkCabang Malang ). Jurnal Aplikasi Manajemen, 10(4), 811820.

[93] Riantoko, R., Sudibya, I. G. A., \& Sintaasih, D. K. (2017). Pengaruh Dukungan Organisasi Terhadap Motivasi Kerja Dan Kinerjaanggota Polsek Kuta Utara. Ekonomi dan Bisnis Universitas Udayana, 3, 1145-1176. https://journal.unnes.ac.id/sju/index.php/maj/article/view/7226

[94] Rozalena, Tahrun, \& Tobari. (2018). The influence of headmasters' kindergarten situational leadership and school's environment toward teachers' performance. International Journal of Scientific and Technology Research, 7(4), 80-92. https://www.ijstr.org/final-print/apr2018/The-Influence-OfHeadmasters-Kindergarten-Situational-Leadership-AndSchools-Environment-Toward-Teachers-Performance.pdf

[95] Saban, D., Basalamah, S., Gani, A., \& Rahman, Z. (2020). Impact Of Islamic Work Ethics, Competencies, Compensation, Work Culture On Job Satisfaction And Employee Performance: The Case Of Four Star Hotels. European Journal of Business and Management Research, 5(1). doi:10.24018/ejbmr.2020.5.1.181

[96] Samah, I. H. A., Shamsuddin, A. S., Rashid, I. M. A., \& Amlus, M. H. (2019). Mediating effect of self-satisfaction, intrinsic motivation and performance. A study on malaysian archers. International Journal of Scientific and Technology Research, 8(12), 29812984. https://www.google.com/url?client=internal-elementcse\&cx=015665522297807158791:e4ankvq01v0\&q=http://www. ijstr.org/final-print/dec2019/Mediating-Effect-Of-Self-satisfactionIntrinsic-Motivation-And-Performance-A-Study-On-MalaysianArchers. pdf\&sa=U\&ved=2ah

[97] sari, W., Qomariah, N., \& Setyowati, T. (2020). The Role of Emotional Intelligence, Spiritual Intelligence And Work Motivation In Improving The Performance of Hotel Employees. International Journal of Economics and Management Studies, 7(6), 112-118. doi:10.14445/23939125/ijems-v7i6p116

[98] Sarwono, S. W. (2005). Psikologi Lingkungan. PT Gramedia Grasindo.

[99] Sedarmayanti. (2011). Manajemen Sumber Daya Manusia. Reformasi Birokrasi dan Manajemen Pegawai Negeri Sipil (Cetakan 5). PT. Refika Aditama.

[100]Sekaran, U. (2006). Metode Penelitian Untuk Bisnis. Salemba Empat.

[101]Setiawati, T. (2017). Pengaruh Kompetensi Kerja Terhadap Kinerja Dosen. Media Pendidikan, Gizi, dan Kuliner, 1(1), 1-5.

[102]Sholehatusya'diah. (2017). Pengaruh Kompetensi Kerja terhadap Kinerja Karyawan Di. eJournal Adminstrasi Negara, 5(2), 57895802.

[103]Simamora, H. (2006). Manajemen Sumberdaya Manusia. Sekolah. Tinggi llmu Ekonomi YKPN.

[104]Siregar, L. A. S., Suhendra, A. A., \& Kamil, A. A. (2020). Improving productivity through work environment, training, health and safety. International Journal of Innovation, Creativity and Change, 13(3), 357-370. https://www.ijicc.net/images/vol_13/lss_3/13351_Siregar_2020_ E_R.pdf

[105]Soebyakto, B. B., Hanafi, A., \& Rakasiwih, E. (2019). Effect Of Training, Motivation, And Job Satisfaction On Employee Performance At Pt Techwin Bkt. International Journal of Scientific and Technology Research, 8(12).

[106]Soetikno, Y. J. (2017). The Influence Of Work Environment And Organizational Culture On Work Satisfaction And Lecturers Performance At The Schools Of Management Information And Computer In Sulawesi. International Journal of Scientific \& Technology Research, 6(4), 132-136. https://www.ijstr.org/final- 


\section{GENERAL MANAGEMENT}

print/apr2018/The-Influence-Of-Headmasters-KindergartenSituational-Leadership-And-Schools-Environment-TowardTeachers-Performance.pdf

[107] Solihin, M., \& Ratmono, D. (2013). Analisis SEM-PLS dengan WarpPLS. Pustaka Pelajar.

[108]Solikah, I., Setyowati, T., \& Sanosra, A. (2016). PENGARUH REWARD, PUNISHMENT DAN MOTIVASI KERJA TERHADAP PRODUKTIVITAS KERJA KARYAWAN PADA PTPN XII ( Persero ) KEBUN JATIRONO KALIBARU. Manajemen Dan Bisnis Indonesia, 2(1), 91-105.

[109]Sriwidodo, U., \& Haryanto, A. B. (2010). Pengaruh Kompetensi, Motivasi, Komunikasi Dan Kesejahteraan Terhadap Kinerja Pegawai Dinas Pendidikan. Jurnal Manajemen Sumberdaya Manusia, 4(1).

[110]Sugiyatmi, Minarsih, M. M., \& Edward Gagah. (2016). Pengaruh Motivasi, Gaya Kepemimpin Dan Lingkungan Kerja Terhadap Disiplin Kerja Serta Dampaknya Terhadap Kinerja Karyawan Di Pt Bina San Prima. Journal Of Management, 2(2). http://jurnal.unpand.ac.id/index.php/MS/article/view/534/520

[111]Sugiyono. (2017). Metode Penelitian Kuantitatif, Kualitatif, dan R\&D. Alfabeta.

[112]Sujana, E. (2012). Pengaruh Kompetensi, Motivasi, Kesesuaian Peran Dan Komitmen Organisasi Terhadap Kinerja Auditor Internal Inspektorat Pemerintah Kabupaten (Studi Pada Kantor Inspektorat Kabupaten Badung Dan Buleleng). Jurnal IImiah Akuntansi dan Humanika, 2(1), 1-27.

[113]Sulistyo, B., Minarsih, M. M., \& Warso, M. M. (2016). Pengaruh Pendidikan Dan Latihan Profesi Guru ( Plpg ), Kedisiplinan Guru , Dan Kompetensi Guru Terhadap Kinerja. journal of Management, 2(2)

[114]Sumowo, S. (2017). ANALISIS DISIPLIN KERJA DAN MOTIVASI KERJA TERHADAP PRESTASI KERJA KARYAWAN PADA LAVA - LAVA HOSTEL DAN RESTO PROBOLINGGO Seno Sumowo Fakultas Ekonomi Universitas Muhammadiyah Jember Email: senosumowo@unmuhjember.ac.id PENDAHULUAN Di dalam kehidupan seha. Jurnal Penelitian IPTEKS, 2, 49-60.

[115]Susanti, N. (2017). EFFECT OF ENVIRONMENTAL WORK AND WORK SATISFACTION OF EMPLOYEE PRODUCTIVITY Sekolah Tinggi Agama Islam ( STAI) Yaptip Pasaman Barat Email : susantinovi57@gmail.com PENDAHULUAN Rumah sakit merupakan tatanan pemberi jasa layanan kesehatan memiliki peran ya. 3(2), 137-154

[116]Suwondo, D. I., \& Sutanto, E. M. (2015). HUBUNGAN LINGKUNGAN KERJA, DISIPLIN KERJA, DAN KINERJA KARYAWAN. Jurnal Manajemen Dan Kewirausahaan (Journal of Management and Entrepreneurship), 17(2). doi:10.9744/jmk.17.2.145-154

[117]Sya'roni, Herlambang, T., \& Cahyono, D. (2018). DAMPAK MOTIVASI, DISIPLIN KERJA DAN KEPEMIMPINAN KEPALA SEKOLAH TERHADAP KINERJA GURU. Jurnal Sains
Manajemen \& Bisnis Indonesia, 8(2), 131-147.

[118]Utomo, A. W., Qomariah, N., \& Nursaid. (2019). The Impacts of Work Motivation, Work Environment, and Competence on Performance of Administration Staff of dr. Soebandi Hospital Jember East Java Indonesia. International Journal of Business and Management Invention (IJBMI, 8(09), 46-52. http://www.ijbmi.org/papers/Vol(8)9/Series-2/G0809024652.pdf

[119]Vidianingtyas, R. N., \& Putri, W. H. (2014). Pengaruh kompensasi, kepuasan kerja, motivasi kerja dan gaya kepemimpinan terhadap kinerja karyawan pada perusahaan jasa katering di daerah istimewa yogyakarta. Efektif Jurnal Bisnis dan Ekonomi, 5(1), 99-110.

[120]Wasiman. (2020). Effect of organizational culture, rewards, competence, and organizational citizenship behavior. International Journal of Scientific and Technology Research, 9(2), 6329-6333.

[121]Wibowo, M. A., \& Putra, Y. S. (2016). PENGARUH MOTIVASI DAN BUDAYA ORGANISASI TERHADAP KEPUASAN KERJA SERTA IMPLIKASINYA TERHADAP KINERJA KARYAWAN PADA RUMAH SAKIT UMUM (RSU) SALATIGA. Among Makarti, 9(1). doi:10.52353/ama.v9i1.124

[122]Wijianto, W., Cahyono, D., \& Qomariah, N. (2020). How To Improve Employee Performance At The Forest Service. INTERNATIONAL JOURNAL OF SCIENTIFIC \& TECHNOLOGY RESEARCH, 9(8), 256-264. www.ijstr.org

[123]Winanti, M. B. (2011). Pengaruh Kompetensi Terhadap Kinerja Karyawan (Survei Pada Pt. Frisian Flag Indonesia Wilayah Jawa Barat). Majalah IImiah UNIKOM, 7(2), 249-267.

[124]Wongso, S. H., Gana, F., \& Kerihi, A. S. Y. (2020). The effect of enterpreneurship motivation, enterpreneurship competency, and financial literation on msmes in kupang city. International Journal of Scientific and Technology Research, 9(2), 5236-5241.

[125]Yamin, M., \& Ishak. (2018). The effect of employees competency, application of performance-based budgeting and functional supervision on the performance (LKD) SKPD. International Journal of Scientific and Technology Research, 7(8), 215-219.

[126]Yohana, C., Rahmat, A., Alam, H. V, \& State, G. (2020). The Effects of Locus of Control, Work Environment and Teacher Performance on Job Satisfaction for Teachers at a Private Vocational High School in Indonesia. International Journal of Innovation, Creativity and Change, 13(8), 351-367. https://www.ijicc.net/images/vol_13/lss_8/13827_Yohana_2020_ E_R.pdf

[127]Zubaidah, R. A. (2016). PENGARUH KEPEMIMPINAN KEPALA SEKOLAH DAN KOMPETENSI GURU TERHADAP MOTIVASI KERJA GURU SERTA IMPLIKASINYA PADA KINERJA GURU DI SMP NEGERI KOTA PALEMBANG. JURNAL Ecoment Global, 1(2), 8-20 http://ejournal.uigm.ac.id/index.php/EG/article/view/200/204 